\title{
PROPORSI BAGIAN TUBUH DAN KADAR PROKSIMAT IKAN GABUS PADA BERBAGAI UKURAN
}

\section{Body Parts Proportion and Proximate Levels of Snakehead on Various Sizes}

\author{
Ruddy Suwandi*, Nurjanah, dan Margaretha Winem \\ Departemen Teknologi Hasil Perairan, Fakultas Perikanan dan Ilmu Kelautan, \\ Institut Pertanian Bogor, Kampus IPB Darmaga, Jalan Agatis, Bogor 16680 Jawa Barat. \\ Telepon (0251) 8622909-8622906, Faks. (0251) 8622907 \\ ^Korespondensi: rdsuwandi@pksplipb.or.id \\ Diterima 01 Januari 2014/Disetujui 02 April 2014
}

\begin{abstract}
Abstrak
Ikan gabus (Channa striata) merupakan jenis ikan air tawar yang sudah banyak dikenal oleh masyarakat Indonesia. Ikan gabus hidup di muara sungai, danau, rawa, dan dapat pula hidup di air kotor dengan kadar oksigen rendah. Ikan gabus belum banyak dibudidayakan secara luas dan belum banyak dimanfaatkan sebagai produk olahan ikan. Informasi mengenai proporsi tubuh ikan gabus masih kurang dan belum banyak dikaji. Penelitian ini bertujuan untuk menentukan proporsi bagian-bagian tubuh ikan dan komposisi kimia daging ikan gabus pada berbagai ukuran $(0,5 \mathrm{~kg} ; 1 \mathrm{~kg}$; dan $2 \mathrm{~kg})$ dan jenis kelamin. Prosedur yang dilakukan pada penelitian ini yaitu pengukuran proporsi tubuh ikan dan analisis proksimat. Ikan gabus betina memiliki rendemen daging yang lebih tinggi dibanding ikan gabus jantan. Rendemen terbesar terdapat pada daging dengan bobot tubuh ikan $2 \mathrm{~kg}$. Kadar air dan kadar abu tertinggi terdapat pada ikan gabus jantan $0,5 \mathrm{~kg}$ yaitu $80,41 \%$ dan 1,47\%. Kadar protein tertinggi yaitu 20,14\% terdapat pada ikan gabus betina $1 \mathrm{~kg}$. Kadar lemak tertinggi terdapat pada ikan gabus jantan $2 \mathrm{~kg}$ yaitu sebesar 1,69\%. Kadar karbohidrat tertinggi terdapat pada ikan gabus betina $2 \mathrm{~kg}$ yaitu 2,71\%.
\end{abstract}

Kata kunci: ikan gabus, proksimat, proporsi tubuh

\section{Abstract}

Snakehead (Channa striata) is a freshwater fish well known by Indonesian people. Snakehead lives in outfall, lakes, swamp, as well as dirty water with low oxygen content. Snakehead is not widely cultivated and utilized yet as the fish processed products. Information on body proportion of snakehead is still lacking. Thus, the purpose of the research was to determine the body parts proportion of fish and chemical composition of flesh on any sizes ( $0.5 \mathrm{~kg} ; 1 \mathrm{~kg}$; and $2 \mathrm{~kg}$ ) and sex. Procedure was carried out by measurement of fish body proportion of fish and proximate analysis. Generally, female type had higher yield of meat than male one. The largest body part of snakehead was found on flesh of fish $2 \mathrm{~kg}$. The highest water and ash levels found on male snakehead $(0.5 \mathrm{~kg})$ were $80.41 \%$ and $1.47 \%$. The highest protein content was $20.14 \%$ found on 1 $\mathrm{kg}$ female snakehead. In other hand, the highest fat content was found on $2 \mathrm{~kg}$ male snakehead (1.69\%). In addition, the highest content of carbohydrate was on $2 \mathrm{~kg}$ female snakehead (2.71\%).

Keywords: body proportions, proximate, snakehead

\section{PENDAHULUAN}

Perairan darat merupakan salah satu jenis perairan yang memiliki biota perairan yang cukup banyak untuk dimanfaatkan. Salah satu biota perairan yang dapat dimanfaatkan dan memiliki nilai ekonomis penting adalah ikan gabus (Channa striata). Ikan gabus merupakan jenis ikan air tawar yang sudah banyak dikenal oleh masyarakat Indonesia. Ikan gabus banyak ditemukan di perairan umum dan belum dibudidayakan secara luas (Bijaksana 2012). Ikan gabus hidup di muara sungai, danau, rawa, dan dapat pula hidup di air kotor dengan kadar oksigen rendah serta tahan terhadap kekeringan. Ikan gabus tersebar luas di Indonesia dan memiliki sebutan yang berbeda- 
beda disetiap daerahnya yaitu gabus, rayong, delek, deleg, kutuk, bado, bace, sepungkat, haruan, bakok, pior, ruting, dan ruan. Daerah papua menyebutnya dengan sebutan ikan gabus, dan untuk daerah Merauke ikan ini disebut gastor (Dwi dan Yulisman 2012).

Ikan gabus memiliki sifat karnivora dan memiliki ciri-ciri tubuh berbentuk hampir bulat, panjang, dan semakin ke belakang berbentuk pipih. Ikan gabus memiliki bagian punggung yang berbentuk cembung dan perut yang rata serta kepala yang pipih. Ikan gabus tidak memiliki jari-jari sirip yang keras. Ukuran tubuh ikan gabus sangat beranekaragam dan dapat mencapai panjang (90-110) $\mathrm{cm}$. Ikan ini di Sumatera Selatan dimanfaatkan dalam bentuk ikan segar yaitu digunakan sebagai bahan pembuatan kerupuk, pempek dan olahan lainnya, karena mengandung nilai gizi yang cukup tinggi (Muthmainnah 2013). Penangkapan ikan gabus di perairan umum dari tahun ke tahun makin meningkat, menurut data statistik KKP produksi ikan gabus di Indonesia dari tahun 2000 hingga 2010 naik sebesar $1,19 \%$, pada tahun 2010 produksinya sebesar 34.017 ton dengan kenaikan produksi dari tahun 2009 sebesar 21,79\%. Produksi ikan gabus di provinsi Papua pada tahun 2010 mencapai 2.285 ton (KKP 2011).

Pemanfaatan ikan ini dari berbagai ukuran, yaitu pada ukuran benih dimanfaatkan sebagai pakan ikan hias, dan pada ukuran konsumsi, ikan ini sangat digemari karena memiliki daging yang tebal dan rasa yang khas. Bentuk olahan kering ikan ini yaitu dijadikan ikan asap atau ikan asin. Pemanfaatan ikan gabus di Jayapura belum banyak, beberapa kelompok masyarakat mengkonsumsi ikan gabus dalam bentuk masakan (dipanggang, digoreng, dimasak berkuah), namun sebagian lagi tidak suka mengkonsumsi ikan gabus toraja karena bentuknya yang menyerupai ular. Ikan gabus umumnya dikonsumsi masyarakat lokal di daerah Merauke sebagai lauk dan belum banyak dimanfaatkan dalam pembuatan berbagai produk olahan lainnya (Bakar et al. 2012). Setiap bagian tubuh ikan gabus memiliki proporsi yang berbeda berdasarkan pada ukuran tubuh dari ikan gabus tersebut sehingga setiap bagian ikan dapat dimanfaatkan sesuai dengan manfaatnya. Penelitian ini bertujuan untuk menentukan proporsi bagian-bagian tubuh ikan dan komposisi kimia daging ikan gabus pada berbagai ukuran $(0,5 \mathrm{~kg} ; 1 \mathrm{~kg}$; dan 2 $\mathrm{kg}$ ) dan jenis kelamin.

\section{BAHAN DAN METODE}

\section{Bahan dan Alat}

Bahan utama yang digunakan yaitu ikan gabus, air, dan es batu. Alat yang digunakan dalam penelitian ini adalah timbangan digital Acis BC5000, tabung Sokhlet, labu Kjeldahl $100 \mathrm{~mL}$, dan labu Erlenmeyer $125 \mathrm{~mL}$.

\section{Metode Penelitian}

Penelitian dilakukan dalam tiga tahap yaitu pengambilan sampel di Distrik Semangga, Kabupaten Merauke; pengkajian proporsi daging ikan gabus; analisis proksimat ikan gabus (AOAC 2005). Data yang diperoleh dianalisis dengan metode deskriptif.

\section{HASIL DAN PEMBAHASAN \\ Morfometrik Ikan Gabus}

Ikan gabus yang digunakan dalam penelitian ini yaitu ikan gabus yang memiliki ukuran atau bobot sebesar $0,5 \mathrm{~kg}, 1 \mathrm{~kg}$, dan $2 \mathrm{~kg}$ yang telah diukur panjang dan lebar totalnya serta dipisahkan antara ikan jantan dan ikan betina. Ikan gabus ini memiliki ciriciri yaitu bentuk tubuhnya bulat, panjang dan semakin ke belakang berbentuk pipih (compressed). Bagian punggung ikan ini cembung, perutnya rata dan kepalanya pipih seperti ular (head snake). Ikan ini memiliki warna tubuh bagian punggung hitam dan perut berwarna putih. Ikan gabus merupakan ikan yang bersifat karnivora atau pemakan segala pada fase hidup yang berbeda pula. Ikan gabus termasuk dalam Famili Channidae dengan nama latin C. striata.

Penelitian yang dilakukan menggunakan ikan gabus yang memiliki panjang rata-rata yang tidak terlalu berbeda antara ikan jantan 
Tabel 1 Panjang dan lebar rata-rata ikan gabus (C. striata)

\begin{tabular}{ccc}
\hline Sampel & Panjang $(\mathrm{cm})$ & Lebar $(\mathrm{cm})$ \\
\hline J05 & $30,73 \pm 1,26$ & $4,43 \pm 0,26$ \\
B05 & $30,39 \pm 1,74$ & $4,68 \pm 0,47$ \\
J1 & $39,15 \pm 2,28$ & $5,91 \pm 0,38$ \\
B1 & $38,03 \pm 2,62$ & $5,91 \pm 0,47$ \\
J2 & $45,91 \pm 1,60$ & $7,16 \pm 0,37$ \\
B2 & $46,08 \pm 2,19$ & $7,53 \pm 0,64$ \\
\hline
\end{tabular}

dan ikan betina. Panjang dan lebar rata-rata ikan gabus pada Tabel 1 menunjukkan bahwa ikan gabus jantan dan betina yang digunakan memiliki ukuran panjang berkisar antara $(30,73 \pm 1,26) \mathrm{cm}$ sampai $(46,08 \pm 2,19) \mathrm{cm}$ dan lebar berkisar antara $(4,43 \pm 0,26) \mathrm{cm}$ sampai $(7,53 \pm 0,64) \mathrm{cm}$ untuk semua ukuran bobot ikan yang digunakan yaitu $0,5 \mathrm{~kg}, 1 \mathrm{~kg}$, dan $2 \mathrm{~kg}$. Panjang maksimum ikan jantan dapat mencapai $100 \mathrm{~cm}$ (Yamamoto dan Tagawa 2000). Lebar maksimum ikan gabus dapat mencapai $12 \mathrm{~cm}$ dan memiliki panjang tubuh mencapai (60-75) cm (Requieron et al. 2012).

\section{Proporsi Bagian Tubuh Ikan Gabus}

Proporsi bagian tubuh ikan gabus antara lain bagian kepala dan insang, daging, tulang, kulit, dan jeroan. Masing-masing bagian tubuh memiliki proporsi yang berbeda-beda berdasarkan ukuran atau bobot ikan gabus tersebut. Bobot rendemen kepala dan insang ikan gabus jantan maupun betina meningkat seiring dengan bertambahnya bobot ikan. Proporsi kepala dan insang ikan gabus jantan maupun betinabertambahsesuai dengan bobot tubuh dari ikan gabus tersebut. Rendemen ikan dipengaruhi oleh pertumbuhan ikan tersebut (Froese 2006). Proporsi daging ikan gabus semakin meningkat atau semakin besar sesuai dengan ukuran bobot ikan. Rendemen terbesar pada ikan gabus adalah daging yang hampir mencapai setengah dari bobot tubuh ikan. Rendemen daging maksimum terdapat pada ikan gabus betina dengan bobot ikan $2 \mathrm{~kg}$. Rata-rata rendemen daging pada ikan gabus betina lebih tinggi dibandingkan dengan ikan gabus jantan, hal ini dapat dipengaruhi oleh perbedaan cara atau kebiasaan makan ikan, serta tingkat kematangan gonad ikan gabus. Ikan gabus jantan dan betina mempunyai kebiasaan makan yang berbeda. Perbedaan Pertumbuhan ikan dipengaruhi oleh beberapa faktor yaitu jenis kelamin, umur, faktor keturunan, dan ketersediaan makanan (War et al. 2011).

Rendemen tulang pada ikan gabus jantan maupun betina memiliki nilai atau bobot yang semakin meningkat berdasarkan ukuran atau bobot tubuhnya. Nilai bobot tulang terkecil yaitu pada bobot tubuh ikan $0,5 \mathrm{~kg}$ dan tertinggi pada bobot $2 \mathrm{~kg}$. Rendemen kulit ikan gabus semakin bertambah nilainya sesuai dengan bobot tubuh ikan tersebut. Nilai proporsi jeroan ikan gabus jantan dan betina menunjukkan sedikit perbedaan, hal tersebut dipengaruhi oleh adanya sel telur pada jeroan ikan yang menambah bobot dari jeroan ikan gabus betina.

Ikan gabus dengan ukuran bobot yang berbeda memiliki panjang tubuh serta proporsi tubuh yang berbeda pula. Ikan gabus jantan dengan bobot yang lebih besar memiliki panjang tubuh yang besar pula, karena panjang tubuh ikan gabus berbanding lurus dengan bobot tubuhnya. Muthmainnah (2013) menyatakan bahwa hubungan antara pertambahan berat tubuh ikan dan pertambahan panjang ikan sangat berhubungan erat. Proporsi bagian tubuh ikan pun ikut bertambah mulai dari kepala hingga jeroan ikan tersebut. Ikan gabus betina memiliki berat tubuh yang berkaitan dengan tingkat kematangan gonad yang secara tidak langsung mempengaruhi proporsi tubuh ikan gabus betina tersebut. Kartamihardja (1994) menyatakan bahwa ikan gabus betina yang terdapat di Waduk Kedungombo Jawa Tengah matang kelamin pada ukuran panjang total $18,5 \mathrm{~cm}$. Ikan gabus mencapai umur kamatangan gonad antara 1 dan 2 tahun dengan ukuran panjang sekitar $25 \mathrm{~cm}$, dan bobot ikan gabus yang matang gonad dapat mencapai 0,22 kg (Manda 2009). 


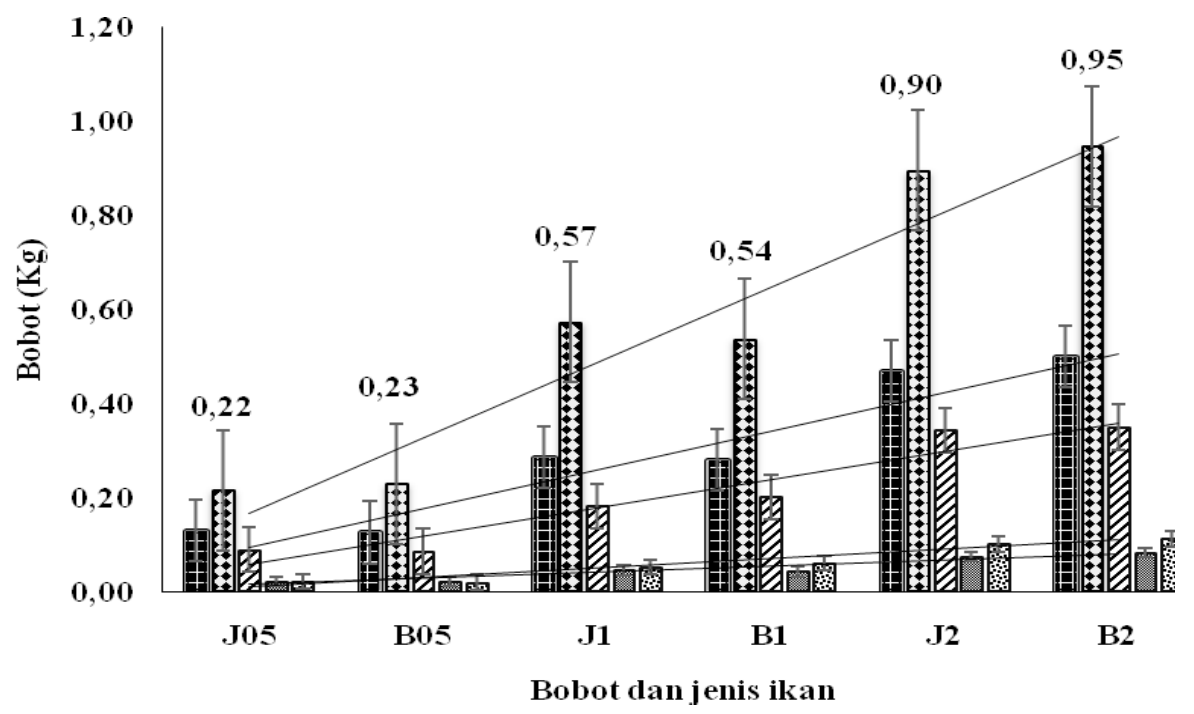

Gambar 2 Proporsi bagian tubuh ikan gabus jantan dan betina. Keterangan: J05 : jantan 0,5 kg; B05: betina 0,5 kg; J1: jantan $1 \mathrm{~kg}$; B1: betina $1 \mathrm{~kg}$ J2: jantan $2 \mathrm{~kg}$; dan B2: betina $2 \mathrm{~kg}$.

(愊) kepala+insang; ( $\mathbf{g})$ daging; (

Hubungan panjang-berat berbeda antar spesies yang berkaitan dengan bentuk tubuh secara genetis, dan di dalam suatu spesies hubungan panjang-berat dipengaruhi oleh kondisi kebugaran individu (Serajuddin et al. 2013). Faktor kondisi ikan seringkali menunjukkan ketersediaan pakan dan pertumbuhan awal ikan yang bersifat dinamis dan bervariasi. Kondisi rata-rata masing-masing populasi bervariasi secara musiman dan tahunan, dan di dalam satu kelompok individu terdapat perbedaan faktor kondisi yang mempengaruhinya. Jenis kelamin dan perkembangan gonad juga memberikan variasi hubungan panjang (Schneider et al. 2000). Chauchan (1987) menyatakan bahwa umumnya bentuk tubuh ikan dapat berubah sepanjang hidupnya dan berat jenis jaringan tubuh dapat berubah.

\section{Komposisi Kimia Ikan Gabus}

Komposisi kimia daging ikan meliputi air, abu, protein, lemak, dan karbohidrat. Kadar air ikan gabus jantan dengan bobot $0,5 \mathrm{~kg}$ memiliki nilai yang paling tinggi yaitu $80,41 \%$ (Tabel 2). Hasil yang diperoleh tidak jauh berbeda dengan hasil kadar air pada penelitian Ahmed et al. (2012) yaitu 82,66\%. Kadar air yang diperoleh antara ikan gabus jantan dan ikan gabus betina pada ketiga ukuran tidak menunjukkan perbedaan nilai kadar air yang besar. Perbedaan kadar air dapat dipengaruhi oleh jenis makanan dan habitat hidup ikan. Daging ikan gabus memiliki kandungan air yang sangat tinggi. Daging pada ikan memiliki kandungan air yang banyak (Restu 2012).

Kadar protein ikan gabus betina dengan bobot $1 \mathrm{~kg}$ memiliki nilai sebesar 20,14\%. Kadar protein yang diperoleh pada ikan gabus dengan jenis kelamin yang berbeda tidak menunjukkan perbedaan nilai yang besar. Kandungan protein yang tinggi pada daging ikan dipengaruhi oleh jenis makanan, habitat, serta ketersediaan makanan. Prasetyo et al. (2012) mengungkapkan bahwa ikan gabus merupakan ikan air tawar yang memiliki kandungan protein lebih tinggi dibanding ikan bandeng, ikan mas, dan ikan kakap. Ikan gabus memiliki kandungan gizi dan albumin yang cukup tinggi daripada ikan yang lain.

Ikan gabus sangat kaya kandungan albumin, salah satu jenis protein penting. Albumin diperlukan tubuh manusia setiap hari, ikan gabus merupakan sumber albumin bagi penderita hipoalbumin (rendah albumin) dan luka. Ikan gabus mempunyai kandungan albumin sebesar 6,22\% (Wahyu et al. 2013).

Kadar lemak ikan gabus jantan dengan 
Tabel 2 Komposisi kimia daging ikan gabus

\begin{tabular}{cccccc}
\hline Sampel & Kadar air (\%) & Kadar protein (\%) & Kadar lemak (\%) & Kadar abu (\%) & Karbohidrat (\%) \\
\hline J05 & $80,41 \pm 0,13$ & $17,44 \pm 1,09$ & $0,09 \pm 0,14$ & $1,47 \pm 0,40$ & $0,59 \pm 0,71$ \\
B05 & $78,55 \pm 0,26$ & $18,01 \pm 0,74$ & $0,42 \pm 0,16$ & $0,56 \pm 0,57$ & $2,46 \pm 0,88$ \\
J1 & $78,25 \pm 0,12$ & $19,34 \pm 0,51$ & $0,90 \pm 0,13$ & $0,71 \pm 0,52$ & $0,80 \pm 0,00$ \\
B1 & $78,19 \pm 0,16$ & $20,14 \pm 1,87$ & $0,81 \pm 0,11$ & $0,72 \pm 0,23$ & $0,14 \pm 1,64$ \\
J2 & $80,22 \pm 0,68$ & $15,33 \pm 3,23$ & $1,69 \pm 1,05$ & $1,12 \pm 0,36$ & $1,64 \pm 2,50$ \\
B2 & $79,77 \pm 1,10$ & $16,82 \pm 1,04$ & $0,33 \pm 0,21$ & $0,37 \pm 0,52$ & $2,71 \pm 0,67$ \\
\hline
\end{tabular}

bobot $2 \mathrm{~kg}$ memiliki nilai sebesar 1,69\% dan ikan gabus betina sebesar 0,33\%. Hasil penelitian ini tidak jauh berbeda dengan hasil yang diperoleh Tsaniyatul et al. (2013) yaitu sebesar $1,75 \%$. Perbedaan nilai kadar lemak dapat disebabkan oleh faktor habitat hidup ikan, jenis kelamin, dan jenis makanan. Kadar abu ikan gabus jantan dengan bobot $0,5 \mathrm{~kg}$ memiliki kandungan abu yang tertinggi yaitu $1,47 \%$. Kandungan abu yang terdapat pada ikan gabus jantan dan betina tidak terlalu berbeda. Hasil tersebut berbeda dengan hasil penelitian Prasetyo et al. (2012) yaitu 4,5\%. Kadar abu ada hubungannya dengan mineral suatu bahan. Perbedaan kadar abu tersebut dipengaruhi oleh habitat hidup ikan gabus. Kandungan abu pada ikan gabus bergantung pada habitat hidup ikan tersebut yang berhubungan dengan kandungan mineral yang terdapat dalam tubuh ikan gabus (Tsaniyatul et al. 2013). Kadar karbohidrat ikan gabus betina dengan bobot $2 \mathrm{~kg}$ memiliki kadar karbohidrat yang tertinggi yaitu 2,71\%. Kandungan karbohidrat meningkat diakibatkan oleh menurunnya kadar protein, lemak, dan abu pada daging ikan (Yulindra et al. 2013).

Kandungan kimia yang terdapat dalam ikan gabus memiliki nilai yang beragam. Berdasarkan berat kering ikan gabus nilai protein yang terkandung sangat tinggi. Distribusi kadar proksimat ikan gabus dalam berat kering disajikan pada Gambar 3. Berdasarkan berat kering protein ikan gabus dapat mencapai 92,34\% dan nilai kadar protein terendah yaitu sebesar $77,50 \%$. Kadar lemak tertinggi yang diperoleh pada berat kering daging ikan gabus yaitu mencapai 8,54\%.

Kadar abu yang dihasilkan berdarkan berat kering daging ikan gabus yang tertinggi yaitu 7,50\%. Perbedaan kadar abu berdasarkan jenis kelamin dan bobot tubuh ikan sendiri

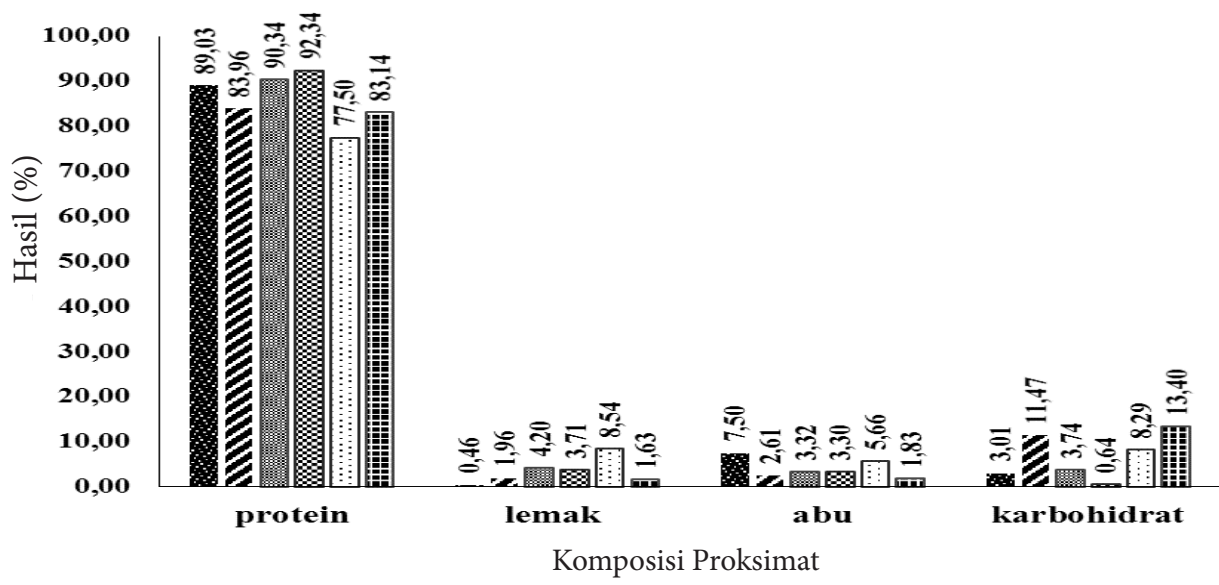

Gambar 3 Kadar proksimat ikan gabus dalam berat kering. Keterangan: (露) jantan 0,5 kg;

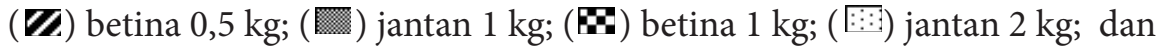

(II) betina $2 \mathrm{~kg}$ 
dapat dipengaruhi oleh jenis makanan dan habitat dari ikan tersebut. Kadar abu yang terkandung dipengaruhi oleh kandungan mineral yang terdapat pada habitat hidup dari ikan gabus tersebut (Wahyu et al. 2013). Kandungan karbohidrat terbesar yaitu 13,40\%, tingginya nilai karbohidrat pada daging ikan dipengaruhi oleh pengurangan kandungan air daging ikan (Aberoumand 2012).

\section{KESIMPULAN}

Rendemen terbesar pada ikan gabus adalah daging yang hampir mencapai setengah dari bobot tubuh ikan. Rendemen daging maksimum terdapat pada ikan gabus betina dengan bobot ikan $2 \mathrm{~kg}$. Kadar Lemak tertinggi pada ikan gabus jantan bobot $2 \mathrm{~kg}$. Kadar karbohidrat tertinggi terdapat pada ikan gabus betina $2 \mathrm{~kg}$. Kadar protein tertinggi terdapat pada ikan gabus betina bobot 0,5 kg. Kadar air dan abu tertinggi terdapat ikan gabus jantan bobot $0,5 \mathrm{~kg}$.

\section{DAFTAR PUSTAKA}

Aberoumand A. 2012. Proximate composition of less known some processed and fresh fish species for determination of the nutritive values in Iran. Journal of Agricultural Technology 8(3):917-922.

Ahmed S, Arifur AFMR, Mustafa G, Belal MH, Nahar N. 2012. Nutrient composition of indigenous and exotic fishes of rainfed waterlogged paddy fields in Lakshmpur, Bangladesh. World Journal of Zoology 7(2):135-140.

[AOAC] Association of Official Analytical Chemist. 2005. Official Method of Analysis of The Association of Official Analytical of Chemist. Arlington, Virginia (US): The Association of Official Analytical Chemist, Inc.

Bakar TA, Kurniaty RM, Mahendradatta M, Suryani. 2012. Difusi teknologi produksi konsetrat protein dari ikan gabus sebagai food supplement di Jayapura. Prosiding Insentif Hasil Riset Sinas. Okt 17-18 Jayapura,Indonesia. Jakarta: Hlm 40-44
Bijaksana U. 2012. Dosmestikasi ikan gabus (Channa striata Blkr), upaya optimalisasi perairan rawa di Provinsi Kalimantan Selatan. Jurnal Lahan Suboptimal 1(1): 92-101.

Chauchan RS. 1987. Food, parasites and length-weight relationship of a hill stream fish, Schizothorax plagiostomus (Heckel). Indian Journal of Animimal Research 21(2):93-96.

Dwi SA, Yulisman. 2012. Pertumbuhan dan kelangsungan hidup benih ikan gabus (Channa striata) yang diberi pakan buatan berbahan baku tepung keong mas (Pomacea sp.). Jurnal Lahan Suboptimal 1(2):158-162.

Froese R. 2006. Cube law, condition factor and weight-length relationships: history, meta-analysis and recommendations. Journal of Applied Ichthyology 22:241253.

Kartamihardja ES. 1994. Biologi reproduksi populasi ikan gabus Channa striata di Waduk Kedungombo. Bogor: Buletin Perikanan Darat 12:113-119.

[KKP] Kementrian Kelautan dan Perikanan, Ditjen Perikanan Tangkap. 2011. Statistik Perikanan Tangkap Indonesia 2010. [internet]. [diunduh 23 September 2013]. Tersedia pada http//www.dkp.go.id.

Manda RP. 2009. Pola lingkaran pertumbuhan otolith ikan gabus (Channa striata) diperairan sungai Siak Propinsi Riau. Berkala Perikanan Terubus 37(2):1-11.

Muthmainnah D. 2013. Hubungan panjang berat dan faktor kondisi ikan gabus (Channa striata Bloch, 1793) yang dibesarkan di Rawa Lebak, Provinsi Sumatera Selatan. Jurnal Depik 2(3):184190.

Prasetyo MN, Sari N, Sri CB. 2012. Pembuatan kecap dari ikan gabus secara hidrolisis enzimatis menggunakan sari nanas. Jurnal Teknologi Kimia dan Industri 1(1): 329-337.

Requieron EA, Anthony MJT, Demayo CG. 2012. Applications of relative warp analysis 
in describing of scale shape morphology between sexs of the snakehead fish Channa striata. International Journal of Biological, Ecological and Environmental Sciences 1(6):2277-4394.

Restu. 2012. Pembuatan bakso ikan toman (Channa micropeltes). Jurnal Ilmu Hewani Tropika 1(1): 1-5.

Schneider JC, Laarman PC, Gowing H. 2000. Length-Weight Relationship, with Periodic Updates. Michigan (US): Michigan Department of Natural Resources, Fisheries Special Report 25. Ann Arbor.

Serajuddin ML, Prasad, Pathak BC. 2013. Comparative study of length-weight relationship of freshwater murrel, Channa punctatus (Bloch 1793) from lotic and lentic environments. World Journal of Fish and Marine Sciences 5(2):233-238.

Tsaniyatul SMS, Dwi TS, Suprayitno E. 2013. Pengaruh suhu pengukuran terhadap kandungan gizi dan organoleptik abon ikan gabus (Ophiocephalus striatus). THPi student Journal 1(1): 33-45.

Wahyu DS, Dwi TS, Eddy S. 2013. Pemanfaatan residu daging ikan gabus (Ophiocephalus striatus) dalam pembuatan kerupuk ikan beralbumin. THPi Student Journal 1(1): 21-32.

War M, Altaff K, Abdulkhader HM. 2011. Growth and survival of larval snakehead Channa striatus (Bloch 1793) fed different live feed organisms. Turkish Journal of Fisheries and Aquatic Sciences 11:523-528. Yamamoto MN, Tagawa AW. 2000. Hawaii's Native and Exotic Freshwater Aniamal. Mutual Publishing. 200p.

Yulindra T, Dwi TS, Suprayitno E. 2013. Pengaruh konsentrasi residu daging ekstraksi albumin ikan gabus (Ophiocephalus striatus) yang berbeda terhadap kualitas sosis ikan. THPi Student Journal 1(2): 51-60. 